\title{
PENYULUHAN MANAJEMEN PEMBERDAYAAN PEREMPUAN DALAM MENINGKATKAN PEREKONOMIAN KELUARGA NELAYAN DI DESA KANGKUNG, BANDAR LAMPUNG
}

\author{
Lia Asmalah, Nurmin Arianto, Iis Noviyanti \\ Program Studi Manajemen \\ Universitas Pamulang \\ Email: dosen01644@unpam.ac.id
}

\begin{abstract}
The Kangkung village in Bandar Lampung is a village where most of the people earn a living as fishermen, so many women in the family have to go down to help the family's economy by going straight to helping the activities of catching marine products. The targets and objectives to be achieved in Community Service Activities (PKM) are giving direction to women from fishing families in the Kangkung village in order to develop their abilities and partitions in improving the family's economy. The method used in this Community Service (PKM) activity is to provide counseling and discussion in the context of socializing Providing guidance to women from fishing families in the kangkung village in order to develop their abilities and partitions in improving the family economy. With this extension, it is expected that women from fishing families in kangkung village will be able to develop their capabilities and participation in improving the family's economy. Through this training women in fishing villages are expected to realize that development and its results should be enjoyed by all levels of society both men and women ". Especially in the aspects of gender women and men should get access to manf, participation and evaluation of the results of development equally and fair.
\end{abstract}

The word Kunct: Extension, Women, Education, Economy

\begin{abstract}
Abstrak
Desa Kangkung di Bandar Lampung adalah desa yang kebanyakan masyarakarya bermata pencaharian sebagai nelayan, begitu banyak perempuan perempuan keluarga tersebut yang harus turun untuk membantu perekonomian keluarga dengan turun langsung membantu kegiatan hasil penangkapan hasil laut. Adapun sasaran dan tujuan yang ingin dicapai dalam kegiatan Pengabdian Kepada Masyarakat (PKM) ini adalah Memberikan pengarahan kepada para perempuan dari keluarga nelayan di desa kangkung agar dapat mengembangkan kemampuan dan partisiasinya
\end{abstract}


dalam meningkatkan perekonomian keluarga. Metode yang digunakan dalam kegiatan Pengabdian Kepada Masyarakat (PKM) ini adalah memberikan penyuluhan serta diskusi dalam konteks mensosialisasikan Memberikan pengarahan kepada para perempuan dari keluarga nelayan di desa kangkung agar dapat mengembangkan kemampuan dan partisiasinya dalam meningkatkan perekonomian keluarga. Dengan adanya penyuluhaa ini diharapkan perempuan dari keluarga nelayan di desa kangkung agar lebih dapat mengembangkan kernampuan dan peran sertanya di dalam peningkatan perekonomian keluarga. Melalui pelatihan ini perempuan desa nelayan diharapkan menyadari bahwa pembangunan dan hasilnya harus dapat dinikmati oleh seluruh lapisan masyarakat baik perempuan maupun laki laki". Terutama di dalam aspek gender pererrpuan dan laki laki hanrs mendapatkan akses manf,aat partisipasi dan evaluasi dari hasil pembangunan dengan setara dan adil.

Kata Kunci: Penyuluhnn, Perempuun, Pemberduyaan, Ekonomi.

\section{A. PENDAHULUAN}

Pengabdian kepada masyarakat merupakan pelaksanaan pengamalan ilmu pengetahuan, teknologi dan seni budaya langsung pada masyarakat secara kelembagaan melalui metodologi ilmiah sebagai penyebaran Tri Dharma Perguruan Tinggi serta tanggung jawab yang luhur dalam usaha mengembangkan kemampuan masyarakat, sehingga dapat mempercepat laju pertumbuhan tercapainya tujuan pembangunan nasional. Kegiatan pengabdian masyarakat merupakan salah satu Tri Dharma Perguruan Tinggi Selain Pendidikan dan Penelitian, sesuai undang-Undang RI Nomor 20 Tahun 2003 tentang Sistem Pendidikan Nasional, pada Pasal 20 ayat 2 dinyatakan: "Perguruan Tinggi berkewajiban menyelenggarakan pendidikan, penelitian dan pengabdian masyarakat". Pada Pasal 24 ayat 2 disebutkan:"Perguruan tinggi memiliki otonomi untuk mengelola sendiri lembaganya sebagai pusat penyelenggaraan pendidikan tinggi, penelitian ilmiah, dan pengabdian masyarakat"

Desa kangkung di bandar lampung adalah desa yang kebanyakan masyaraktnya bermata pencaharian sebagai nelayan, begitu banyak perempuan perempuan keluarga tersebut yang harus turun untuk membantu perekonomian keluarga dengan turun langsung membantu kegiatan hasil penangkapan hasil laut. Untuk itu perlu adanya pengarahan untuk mebantu perempuan permpuan keluarga nelayan untuk dapat mengembangkan kemampuan usaha dan ide usahanya agar dapat meningkatkan pendapatan selain dengan kegiatan mengelola hasil laut. Menurut Hasibuan (2012:1) Manajemen yaitu: "Ilmu dan seni mengatur proses pemanfaatan sumber daya manusia dan sumber-sumber lainnya secara efektif dan efisien untuk mencapai suatu tujuan tertentu". Sedangkan menurut Manullang (2012:5) Manajemen yaitu: "seni ilmu perencanaan, pengorganisasian, dalam pengabdian kali ini, dimaksudkan untuk penyusunan, pengarahan dan pengawasan untuk mencapai tujuan yang sudah ditetapkan".Sasaran kegiatan Pengabdian kepada masyarakat (PKM) ini adalah dengan mengajak masyarakat desa, untuk mengikuti "Penyuluhan Manajemen Pemberdayaan 
Perempuan dalam Meningkatkan Perekonomian Keluarga Nelayan di Desa Kangkung, Bandar Lampung".

\section{B. METODE PELAKSANAAN KEGIATAN}

Metode yang digunakan dalam kegiatan Pengabdian Kepada Masyarakat (PKM) ini adalah memberikan penyuluhan serta diskusi dalam konteks mensosialisasikan Memberikan pengarahan kepada para perempuan dari keluarga nelayan di Desa Kangkung yang beralamat Jalan. Ikan Sepat, Kelurahan Kangkung, Kecamatan Bumi Waras, Bandar Lampung. Dan waktu pelaksanaan: 01-02 Desember 2019, pukul 15.00 WIB sampai dengan selesai. Adapun tahapan-tahapan yang dilakukan dalam kegiatan ini yaitu:

1. Tahapan Persiapan

a. Mengirimkan proposal kegiatan Pengabdian Kepada Masyarakat (PKM) kepada Universitas Lampung.

b. Universitas lampung mengarahkan kegiatan dilaksanakan di salah satu Desa Binaan mereka yaitu di Desa Kangkung. Karena desa tersebut merupakan desa nelayan yang mempunyai potensi besar dalam hal pengolahan ikan sehingga sangat dibutuhkan adanya peningkatan manajemen peran serta perempuan dalam perekaonomian keluarga.

c. Pembagian kerja (jobdesk) anggota kelompok PKM.

d. Penyusunan bahan/materi yang akan dibawakan saat kegiatan PKM berlangsung.

2. Tahapan Pelatihan

a. Melakukan pemetaan terhadap kegiatan perempuan di desa kangkung mengenai apa saja yang telah dilakukan perempuan di desa kangkung

b. Memberikan materi mengenai pentingnya peran serta perempuan dalam peningkatan perekonomian keluarga di desa kangkung

c. Memberikan materi peningkatan keahlian perempuan nelayan di dalam pengolahan produk perikanan

d. Memberikan pelatihan manajemen pengelolaan keuangan keluarga nelayan di desa kangkung

e. Mengadakan sesi diskusi untuk saling memberikan informasi mengenai kesulitan dan hambatan dalam pemberdayaan perempuan di desa kangkung.

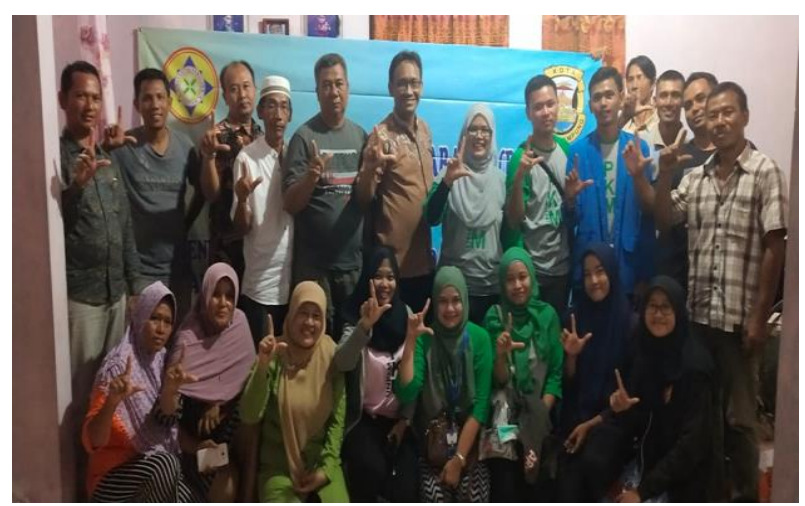

.Gambar 1.1

Pasca Pemberian Materi 


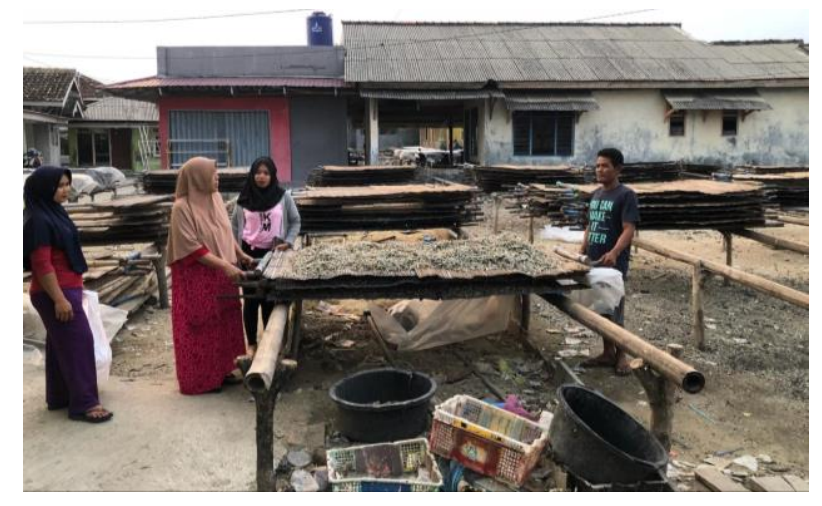

Gambar 1.2 Proses Penjemuran Ikan

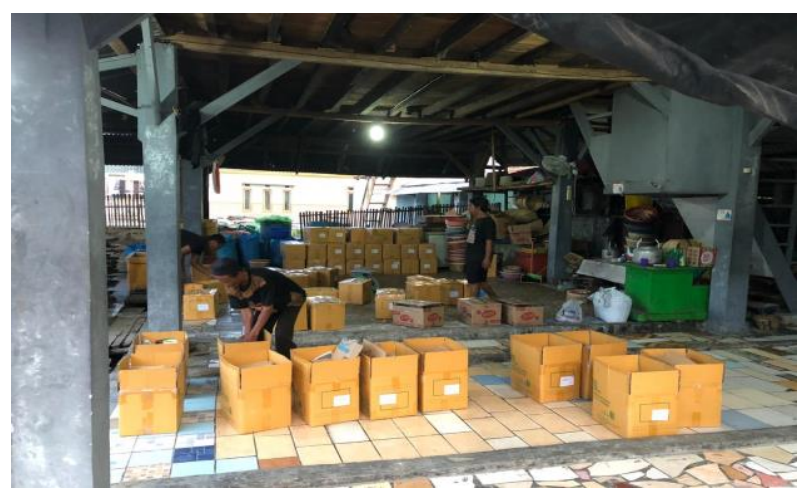

Gambar 1.3

Proses Pengemasan Ikan Yang Baik

\section{HASIL DAN PEMBAHASAN}

Dengan adanya penyuluhan ini diharapkan perempuan dari keluarga nelayan di desa kangkung agar lebih dapat mengembangkan kemampuan dan peran sertanya di dalam peningkatan perekonomian keluarga. Melalui pelatihan ini perempuan desa nelayan diharapkan menyadari bahwa pembangunan dan hasilnya harus dapat dinikmati oleh seluruh lapisan masyarakat baik perempuan maupun laki laki. Terutama di dalam aspek gender perempuan dan laki laki harus mendapatkan akses manfaat partisipasi dan evaluasi dari hasil pembangunan dengan setara dan adil.

Dalam materi pertama oleh Feb Amni Hayati, disampaikan bahwa Perempuan dan lakilaki memiliki peran dan kedudukan yang setara di dalam mencapai tujuan negara serta di dalam memperjuangkan kesejahteraan di semua bidang pembangunan, seperti bidang pendidikan, ekonomi, sosial, politik dan hukum. Perempuan dan laki-laki juga mempunyai kesempatan, akses serta peluang yang sama, sebagai sumber daya pembangunan sebagaimana target yang harus dicapai dalam tujuan pembangunan nasional jangka menengah dan jangka panjang maupun Millenium Development Goal(MDGs) yang akan datang. 
Kaum perempuan Indonesia tidak hanya menjadi pengguna hasil pembangunan, namun juga ikut berperan melaksanakan dan berpartisipasi di segenap aspek pembangunan nasional. Peran politik berarti ikut serta dalam proses pengambilan keputusan dalam upaya membentuk keluarga, masyarakat, bangsa dan negara. Perempuan mempunyai posisi yang lebih dekat dengan keluarga dan telah menggunakan sebagian besar waktunya untuk keluarga, anak dan orang tua.

Oleh karena itu spesifik kaum perempuan akan lebih terdukung apabila perempuan memperoleh akses, dan dapat berpartisipasi serta melakukan kontrol di segenap aspek pembangunan nasional. Padaintinya perempuan memiliki hak asasi yang sama, dan itu integral dalam hak asasi manusia. Oleh karena itu semua pihak harus turut memelihara kodrat, harkat dan martabat perempuan sebagai Ibu Bangsa yang dapat membina keluarga yang harmonis dan sejahtera. Pergerakan perempuan dalam pembangunan, tentunya tidak terlepas dari dukungan semua pihak, baik pemerintah, dunia usaha ataupun masyarakat. Prinsip "equal partnership". Prinsip ini mencerminkan bagaimana perempuan Indonesia bersama kaum laki-laki berperan membangun bangsa, sekaligus juga berperan aktif membangun kesejahteraan dan menjalankan perannya dalam masyarakat secara optimal.

Materi kedua disampaikan oleh Dr.Ir. Gunardi Djoko Winarno selaku dosen Universitas Negri Lampung (Unila). Materi disampaikan sekaligus dengan melihat praktek kegiatanperemuan di desa Kangkung dalam pengolahanproduk turunan ikan. Dalam materinya Dr. Gunardi membahas tentang pentingnya diversivikasi produk perikanan. Diantaranya adalah agar produk perikanan memiliki nilai tambah dan umur yang lebih panjang. Pembuatan ikan asin dan kerupuk adalah salah satu cara untuk memperpanjang umur produk. Saat ini produk olahan ikan sudah beraneka ragam. Dari Universitas Negri Lampung akan secara rutin memberikan pelatihan terkait diversivikasi produk perikanan.

Dalam materi ketiga yang disampaikan oleh Iis Noviyanti, ditekankan pada pentingnya pengelolaan keuangan dalan keluarga. Kegiatan tersebut selama ini mungkin menjadi suatu yang biasa dilakukan, tetapi belum efektif. Sebagian besar perempuan tidak melakukan pemisahan pencatatan keuangan rumah tangga dengan keuangan usaha yang dikelola oleh keluarga. Sebagian malah tidak melakukan pencatatan sama sekali.

Tidak adanya pemisahan dalam pencatatan keuangan keluarga dengan keuangan yang dikelola oleh keluarga akan menyebabkan tidak terukurnya pertumbuhan usaha yang dilakukan. Demikian pula halnya jika tidak dilakukan pencatatan keuangan. Pengeluaran keluarga menjadi tidak terkontrol dan peningkatan/pertumbuhan usaha menjadi stagnan karena tidak adanya pembaharuan investasi.

\section{KESIMPULAN DAN SARAN}

\section{Kesimpulan}

Kegiatan Pengabdian Kepada Masyarakat (PKM) yang telah kami lakukan ini pada dasarnya adalah berkat kerjasama berbagai pihak terkait sehingga kegiatan dapat berjalan dengan baik dan terukur, serta materi yang kami sampaikan dapat bermanfaat bagi perempuan dan keluarga nelayan di desa kangkung, bandar lampung. Dengan adanya kegiatan Pengabdian Kepada Masyarakat (PKM) ini, diharapkan peserta dapat mengaplikasikan ilmu yang telah mereka peroleh dalam kehidupan sehari-hari. Dan pada 
akhirnya, ilmu tersebut dapat dirasakan manfaatnya oleh peserta sendiri dan lingkungan di sekitarnya, khususnya lingkungan keluarg nelayan desa kangkung.

\section{Saran}

Dari hasil pengabdian kepada masyarakat ini kami merekomendasikan kepada pemerintah dan dinas setempat agar :

1. Perempuan mendapatkan akses yang sama di dalam pendidikan agar lebih berdayaguna di dalam masyarakat.

2. Pemerintah secara berkala mengevaluasi pembinaan-pembinaan yang telah dilakukan apakah telah berjalan efektif ataukah belum.

3. Karena keterbatasan nelayan di dalam memasarkan produknya maka diharapkan agar pemerintah dapat membantu nelayan untuk memperluas akses produk produk nelayan.

4. Agar mobilitas desa kangkung dapat berjalan dengan lebih baik maka fasilitas umum terutama jalan dan jembatan harus mendapat perhatian yang cukup.

5. Pemerintah dapat menjalin kerjasama dengan Universitas setempat untuk meningkatkan peran serta perempuan dalam pembangunan terutama didalam peningkatan akses manfaat partisipasi dan evaluasi pemberdayaan yang telah dilakukan.

\section{DAFTAR PUSTAKA}

A. A. Anwar Prabu Mangkunegara, (2013), Manajemen Sumber Daya ManusiaPerusahaan, Remaja Rosdakarya, Bandung.

Ambar, Teguh Sulistiyani. (2004). Kemitraan dan Model-Model Pemberdyaan. Yogyakarta: Cava Media.

Edy Sutrisna. ZAW. Manajemen Sumber Daya Manusia. Cetakan ke-8. Jakarta :Prenada Media Group

Handoko, (2013). Manajemen; Edisi Kedua, Cetakan Ketiga belas, BPFE Yogyakarta.

Hasibuan, Malalu S.P. (2012). Manajemen Sumber Daya Manusia. Jakarta: PT.Bumi Aksara.

Hasibuan, Malalu S.P. (2016). Manajemen Sumber Daya Manusia. Edisi Revisi. Jakarta: Penerbit PT Bumi Aksara.

Hasibuan, Malayu S.P.. ZAfi. Manajemen Sumber Daya Manusia. Edisi Revisi. Jakarta: Bumi Aksara.

Manullang, (2012). Dasar-dasar Manajemen Bagi Pimpinan Perusahaan. Jakarta. Gajah Mada Press.Arikunto,

Nugroho, Riant. (2008). Public Policy. PT Elex Media Komputindo: Jakarta.

Suharsimi. (2013). Prasedur Penelitian Suatu Perdekatan Prakek, PT. Rineka Cipta, Jakarta. 